\title{
Effect of exogenous somatotropin in Holstein calves on mammary gland composition and proliferation
}

\author{
B. P. Huderson, ${ }^{\star}$ B. T. Velayudhan, ${ }^{\star}$ R. E. Pearson, ${ }^{\star}$ S. E. Ellis, $†$ and R. M. Akers ${ }^{\star 1}$ \\ *Department of Dairy Science, Virginia Polytechnic Institute and State University, Blacksburg 24061 \\ †Department of Animal Sciences, Clemson University, Clemson, SC 29634
}

\begin{abstract}
Pubertal mammary gland growth and development are hormonally regulated, but the details are poorly understood in calves. Our purpose was to evaluate the effects of exogenous growth hormone $(\mathrm{GH})$ on the biochemical composition of the prepubertal mammary gland, mRNA expression of selected genes, and histological characteristics of the developing parenchyma (PAR). In this experiment, 19 calves ( $7 \pm 4 \mathrm{~d}$ of age) were randomly assigned to 1 of 2 treatments: bovine somatotropin (bST, $500 \mathrm{mg} ; \mathrm{n}=10$ ) or placebo (Sal; $0.9 \%$ saline; $\mathrm{n}=9$ ). Animals were treated every $3 \mathrm{wk}$ beginning on $\mathrm{d} 23$. Calves were assigned to an early (65 $\mathrm{d}$; tissue harvested after 2 treatment injections) or late collection time $(107 \mathrm{~d}$; tissue harvested after 4 treatment injections). Calves were fed milk replacer and calf starter for 8 wk and starter and hay thereafter. Parenchyma and mammary fat pad (MFP) from one udder half were harvested for analysis of protein, lipid, and DNA. Additional tissues were preserved for histological analysis or snap-frozen for quantitative real-time PCR. Somatotropin treatment did not significantly alter the mass of PAR or MFP or the general pattern of development of epithelial structures. Significant increases were observed in protein $/ 100 \mathrm{~kg}$ of body weight $(\mathrm{BW})$, total protein, DNA concentration, DNA/100 kg of BW, and total DNA in 107-d calves, and a significant treatment by day interaction was observed for DNA and lipid concentrations in PAR. In MFP, a significant decrease was observed in protein $/ 100 \mathrm{~kg}$ of $\mathrm{BW}$ in bST-treated calves and in total MFP protein in 65-d calves. A treatment by day interaction was found for total protein, DNA, and protein $/ 100 \mathrm{~kg}$ of $\mathrm{BW}$. In PAR, relative expression of ATPase-binding cassette 3 and growth hormone receptor were reduced by bST and both were lower in 107-d-harvest calves. Epithelial cell retention of bromodeoxyuridine (BrdU; possible indicator of stem-like cells) was greatest in 65-d bST-treated calves,
\end{abstract}

Received February 2, 2011.

Accepted June 17, 2011.

${ }^{1}$ Corresponding author: rma@vt.edu and a significant time of sampling response and treatment $\times$ time interaction were observed. Expression of the proliferation marker protein Ki67 was numerically higher in bST-treated calves but the difference was nonsignificant. Retention of the BrdU label was reduced in 107-d calves. Exogenous growth hormone given to calves may affect mammary tissue composition and epithelial cell gene expression in subtle ways but exogenous supplementation with bST alone is not likely to alter overall development patterns or affect the mass of mammary parenchymal tissue. Whether such subtle changes have an effect on subsequent development or function is unknown.

Key words: mammary, bovine somatotropin, heifer, stem cell

\section{INTRODUCTION}

As an organ, the mammary gland is unique in that most of its development occurs after birth. Early in life, the ruminant gland consists of little more than stroma and fat pad with rudimentary teat, gland cistern, and some major mammary ducts (Akers, 2002). After about 3 mo of age, the mammary gland enters a period of rapid ductal expansion (allometric growth) that continues until about 9 mo of age (Sinha and Tucker, 1969; Meyer et al., 2006). However, recent observations (Capuco and Akers, 2010; R. M. Akers and S. E. Ellis, personal observations) strongly suggest that this relative change in mammary parenchyma begins much earlier; that is, between 30 and $45 \mathrm{~d}$ of age. In fact, we have measured a 60 -fold increase in mammary parenchyma between 30 and $90 \mathrm{~d}$ of age. During this same period, overall BW approximately doubles. Allometric growth is sensitive to both nutritional and hormonal perturbation. For instance, mammary gland growth is significantly retarded by overfeeding in the later stages of the prepubertal period, resulting in reduced milk yield (Tucker, 1981; Sejrsen et al., 1983). However, overfeeding during postpuberty appears to have no ill effect on mammary growth or subsequent lactations (Tucker, 1981). Although the exact mechanism for regulation of growth and development during this period is unclear, tools to 
manipulate mammary growth could have subsequent practical implications.

Somatotropin (growth hormone, GH) is important in mammary gland development. In now classic rodent endocrine ablation studies (triply operated with pituitary, ovary, and adrenal removed), replacement with GH in combination with estrogen stimulated ductal growth (Lyons, 1958; Tucker, 1981). Furthermore, exogenous GH is known to stimulate mammary growth in various ruminants (Tucker, 1981). Indeed, subsequent studies have shown that exogenous GH increases proliferation of epithelial cells and parenchymal (PAR) mass in older peripubertal heifers (Sejrsen et al., 1986; Berry et al., 2003a). Low levels of circulating GH are correlated with reduced mammary growth measured in over-fed heifers (Capuco et al., 1995; Sejrsen et al., 2000).

A search of the literature shows a plethora of studies examining the role of GH in mammary gland development. However, almost all of these studies are focused on peripubertal and older animals. We have examined the possibility that the naïve calf mammary gland provides a unique window for manipulation of mammary development. Thus, our objectives were to evaluate the effects of exogenous GH on the biochemical composition of the calf mammary gland, mRNA expression of selected genes, and variation in selected histological markers.

\section{MATERIALS AND METHODS}

\section{Animals}

The Virginia Tech Institutional Animal Care and Use Committee approved all animal procedures. Twenty-one newborn Holstein calves were purchased within 2 wk of birth $(7 \pm 4 \mathrm{~d})$ from a Florida dairy. Two calves died before the start of the study for reasons unrelated to the experiment. Prior to leaving the commercial dairy, calves were fed $1 \mathrm{~L}$ of colostrum and passive transfer of immunity was assessed via measurement of serum total protein; animals with total protein $<5.5 \mathrm{~g} / \mathrm{dL}$ were excluded from the study (range in study calves: 5.5-7.5 $\mathrm{g} / \mathrm{dL}$ ). Calves received a $2-\mathrm{mL}$ intranasal dose of Nasalgen (Schering-Plough, Omaha, NE) before transport.

Upon arrival at the Virginia Tech Dairy Center, calves were weighed $(39.4 \pm 4.0 \mathrm{~kg})$ and vaccinated. Calves were immediately offered $1.89 \mathrm{~L}$ of warm electrolytes by nipple bottle and within $12 \mathrm{~h}$ of arrival were offered $1.89 \mathrm{~L}$ of commercially available milk replacer. All additional feedings consisted of twice-daily feedings of standard commercially available milk replacer via nipple bucket. Calves were offered standard calf starter and water ad libitum. At weaning (approximately 8 wk), calves were fed concentrate and hay ad libitum.
Calves were exposed to ambient temperatures during a 3 -wk adaptation period before the onset of treatments. Calves were individually housed in open hutches bedded with gravel and straw. Calves were moved to a freestall barn upon weaning.

Upon arrival at Virginia Tech Dairy Center, calves were randomly assigned to treatment with either bST (500 mg; $\mathrm{n}=10$; Posilac, Monsanto Co., St Louis, MO) or placebo (Sal; $0.9 \%$ saline; $\mathrm{n}=9$ ) treatments. Within treatment, animals were assigned to an early (65 d at tissue harvest) or late (107 d at tissue harvest) harvest point. Treatments were initiated on d 23 and repeated every $21 \mathrm{~d}$. Calves were administered subcutaneous injections in the region over the scapula. Animals in the 65-d harvest group received 2 injections and were harvested $21 \mathrm{~d}$ after the second injection. Animals in the 107-d harvest group received 4 injections and were harvested $21 \mathrm{~d}$ after the fourth injection. Beginning with the second treatment injections, animals were intravenously infused with $5 \mathrm{mg} / \mathrm{kg}$ of BW of bromodeoxyuridine (BrdU) daily for 5 consecutive days. The BrdU (Sigma Chemical Co., St. Louis, MO) solution was prepared in sterile physiological saline at a concentration of $20 \mathrm{mg} / \mathrm{mL}$ (pH 8.5). This was to evaluate the presence of label-retaining cells (possible stem cells) at the time of tissue harvest (Capuco, 2007; Capuco et al., 2009). Animals were weighed every $14 \mathrm{~d}$ starting on 23 d. One calf was dropped from the study after harvest due to chronic illness.

\section{Blood Sampling and Processing}

Blood samples were collected via jugular venipuncture $24 \mathrm{~h}$ before and $24 \mathrm{~h}$ after treatment injection. Samples were collected in vacuum tubes containing either sodium heparin or no anticoagulant. After collection, samples were held on ice and transported to the laboratory for processing. Samples collected in sodium heparin tubes were centrifuged at $2,000 \times g$ at $4^{\circ} \mathrm{C}$ for $20 \mathrm{~min}$. Plasma was aliquoted to $12-\times 75-\mathrm{mm}$ polypropylene tubes and stored at $-20^{\circ} \mathrm{C}$ for future IGF-I analysis. Samples collected in tubes without anticoagulant were allowed to clot at room temperature (RT; $24^{\circ} \mathrm{C}$ ) for 3 to $6 \mathrm{~h}$ and were then stored for $24 \mathrm{~h}$ at $4^{\circ} \mathrm{C}$. Samples were centrifuged at $2,000 \times g$ at $4^{\circ} \mathrm{C}$ for 20 min, and the serum was aliquoted and stored at $-20^{\circ} \mathrm{C}$ for future $\mathrm{GH}$ analysis.

\section{Mammary Tissue Harvesting}

Calves were killed by phenobarbitol injection (Euthasol, $10 \mathrm{mg} / \mathrm{kg}$ of BW; Virbac Co., Fort Worth, TX). Udders were immediately removed, weighed, and bisected along the medial suspensory ligament. Half 
of each udder was snap-frozen in liquid nitrogen and stored at $-80^{\circ} \mathrm{C}$ for later use in biochemical analysis. Mammary fat pad (MFP) and PAR were dissected from the remaining udder half. Tissue samples were divided and snap-frozen in liquid nitrogen and stored at $-80^{\circ} \mathrm{C}$ until RNA was extracted. Samples of PAR and MFP tissue were fixed in 10\% neutral buffered formalin for later use in histological measurements and immunocytochemical analysis.

\section{Hormone Assay}

Concentrations of IGF-I and GH were determined using double-antibody RIA. All samples were run in duplicate in a single assay. Prior to IGF-I assay, binding proteins were acid-ethanol extracted as described previously by Sharma et al. (1994). Plasma concentrations of IGF-I were measured as described by Weber et al. (1999) and Berry et al. (2003a). Briefly, recombinant human IGF-I (Grow Prep, Adelaide, Australia) was used for iodination and standards. Iodination was carried out as described for $\alpha$-lactalbumin (Akers et al., 1986). Mouse anti-human IGF-I primary antibody $(1: 70,000)$ was a gift from Bernard Laarveld (University of Saskatchewan, Saskatchewan, Canada). Goat anti-mouse secondary antibody (1:20) was purchased from Sigma Chemical Company. Serum concentrations of GH were measured as described previously by McFadden et al. (1990) and Berry et al. (2003a). Recombinant bovine GH (lot 6958C-42A; American Cyanamid Co., Princeton, NJ) was used for iodination and standards. Iodination was carried out as described for o-lactalbumin (Akers et al., 1986). Rabbit anti-ovine GH primary antibody (1:100,000; NIDDK-anti-oGH-2; AFP-C0123080) was a gift from the National Hormone and Pituitary Program (Baltimore, MD). Ovine antirabbit gamma globulin was used at a final concentration of 1:15. Intraassay CV was $9.3 \%$.

\section{RNA Extraction and Quantitative Real-Time PCR}

Mammary PAR and MFP samples were homogenized using a Pro 200 Tissue Homogenizer (Pro Scientific Inc., Oxford, CT) in Tri reagent (1.5 mL of Tri Reagent/200 mg of tissue; Molecular Research Center Inc., Cincinnati, OH). Homogenized tissue was incubated at RT for 5 min. Samples were separated into aqueous and organic phases with the addition of 300 $\mu \mathrm{L}$ of chloroform. Samples were mixed, incubated at RT for $15 \mathrm{~min}$, and then subjected to centrifugation $(12,000 \times g)$ at $4^{\circ} \mathrm{C}$ for $15 \mathrm{~min}$. The resulting aqueous phase was combined with $750 \mu \mathrm{L}$ of isopropanol, incubated at RT for $8 \mathrm{~min}$, and centrifuged at 12,000 $\times g$. Precipitated RNA was washed in ethanol $(75 \%$ ethanol in RNase-free water) and centrifuged, and the resulting pellet was air-dried. Dried pellets were resuspended in diethyl pyrocarbonate (Sigma-Aldrich, St. Louis, MO)-treated water. Concentration and purity of extracted RNA were determined using a Nanodrop ND1000 Spectrophotometer (Nanodrop Technologies Inc., Wilmington, DE). Samples with a ratio of optical measurement (optical density, OD) at 260 and $280 \mathrm{~nm}$ (OD $260 \mathrm{~nm} / \mathrm{OD} 280 \mathrm{~nm}$ ) >1.8 were used. Single-stranded cDNA was reverse transcribed from total RNA using a High Capacity cDNA Reverse Transcription Kit (Applied Biosystems, Foster City, CA). Briefly, $20 \mu \mathrm{g}$ of RNA was reverse transcribed in a final reaction volume of $20 \mu \mathrm{L}$ containing $0.02 \mathrm{U}$ of RNase inhibitor using random primers. Resulting cDNA was diluted 1:10 and used in quantitative real-time PCR reactions. Two microliters of diluted cDNA was combined with $12.5 \mu \mathrm{L}$ of SYBR Green dye (Applied Biosystems), $9.5 \mu \mathrm{L}$ of sterile distilled water, $0.5 \mu \mathrm{L}$ of $10 \mu M$ forward and reverse primers. Real-time PCR conditions were $95^{\circ} \mathrm{C}$ for $10 \mathrm{~min}, 95^{\circ} \mathrm{C}$ for $15 \mathrm{~s}$, and $60^{\circ} \mathrm{C}$ for 1 min, and the reaction was performed in a 7300 Series Real-Time System (Applied Biosystems). Data were analyzed using SDS software that was part of the 7300 Series System. Cycle thresholds $(\mathbf{C t})$ values of genes of interest were normalized $(\Delta \mathrm{Ct})$ using the geometric mean of 3 endogenous reference genes: PPP1R11 (forward, 5c-CCATCAAACTTCGGAAACGG-3'; reverse 5'-ACAGCAGCATTTTGATGAGCG-3'), RPS15A (forward, 5'-GAATGGTGCGCATGAATGTC-3'; reverse, 5'-GACTTTGGAGCACGGCCTAA-3'), and MTG1 (forward, 5'-CTTGGAATCCGAGGAGCCA-3'; reverse, 5'-CCTGGGATCACCAGAGCTGT-3'). These genes were previously determined to be appropriate reference or housekeeping genes specifically for prepubertal bovine mammary tissue (Piantoni et al., 2008). Data was expressed as fold difference, calculated as $2^{(-\Delta \Delta \mathrm{Ct})}$. Target genes were proliferating cell nuclear antigen (PCNA; forward, 5'-TCG TCT CAG GCG TTC ATA GTC-3', reverse, 5'-AAC ATG GTG GCG GAG TCG-3'), ATP-ase binding cassette-3 (ABC3; forward, 5'-GCC ACC TTC CTC GTT GTC-3', reverse, 5'-AAG TTG CTC ACT GCC ATC C-3') and growth hormone receptor (GHR; forward, 5'-CGTCTCTGCTGGTGAAAACA-3', reverse, 5'-AACGGGTGGATCTGGTTGTA-3'). Primers were designed using Primer Express Software 3.0 (Applied Biosystems) and purchased from Integrated DNA Technologies (Coralville, IA). All primers were diluted to $10 \mu M$ in RNase-/ DNase-free water. Efficiency of endogenous reference genes and target genes was tested using 5 dilutions of cDNA in duplicate. The primer pairs used exhibited amplification efficiencies ranging between 90 and $110 \%$. Endogenous reference genes were validated for each 
target gene to confirm that the slope of $\Delta \mathrm{Ct}$ versus log cDNA input was $<0.1$. Dissociation curves were run on all samples to detect primer dimers, contamination, or presence of other amplicons.

\section{Proximate Analysis}

Snap-frozen half glands were thawed on ice and dissected. Weights were recorded for skin/teat, lymph nodes, PAR, MFP, and half-gland. Parenchyma and MFP were pulverized to powder in a freezer mill (6950 Freezer Mill; Spex Sample Prep, Metuchen, NJ). Pulverized samples were homogenized in high-salt buffer (0.05 $M \mathrm{NaPO}_{4}, 2 M \mathrm{NaCl}, 0.002 M$ EDTA). Briefly, approximately $250 \mathrm{mg}$ of powdered tissue was suspended in $1.5 \mathrm{~mL}$ of high-salt buffer and homogenized using a PRO200 Homogenizer (PRO Scientific, Oxford, $\mathrm{CT}$ ). Homogenates were centrifuged at $100 \times g$ at $4^{\circ} \mathrm{C}$ for $5 \mathrm{~min}$ to remove tissue debris, and the cleared supernatant was used for protein and DNA concentration determinations.

Protein concentrations of PAR and MFP homogenates were determined using a bicinchoninic acid-based colorimetric assay (Pierce, Rockford, IL) using BSA as a standard. Average intraassay CV was $3.4 \%$. For DNA, $2 \mu \mathrm{L}$ of PAR or MFP homogenate was added to $1.9 \mathrm{~mL}$ of assay buffer $\left(2 \mathrm{M} \mathrm{NaCl}, 10 \mathrm{mM} \mathrm{Na} \mathrm{NaDTA}_{2}\right.$, 10 $\mathrm{m} M$ Tris, $\mathrm{pH} 7.4$ in distilled $\mathrm{H}_{2} \mathrm{O}$ ). Hoechst dye H33258 $(100 \mu \mathrm{L})$ was added to initiate the assay. Calf thymus DNA (Sigma Chemical Co.) was used as the standard. Samples were assayed using a Hoefer DQ 300 fluorometer (Hoefer Inc., San Francisco, CA). All samples were measured in duplicate and the average intraassay $\mathrm{CV}$ was $3.4 \%$.

Lipid content was determined using the hexane:isopropanol method as described by Hara and Radin (1978). Briefly, $9 \mathrm{~mL}$ of hexane:isopropanol (3:2, vol:vol; $0.005 \%$ butylated hydroxytoluene, Sigma Chemical Co.) was added to $500 \mathrm{mg}$ of powdered tissue in preweighed, acid-washed glass tubes. Samples were vortexed for $30 \mathrm{~s}$ following the addition of $6 \mathrm{~mL}$ of sodium sulfate $\left(1 \mathrm{~g}\right.$ of $\mathrm{Na}_{2} \mathrm{SO}_{4}$ per $15 \mathrm{~mL}$ of $\mathrm{H}_{2} \mathrm{O}$ ). Phases were allowed to separate and the tubes vortexed a second time. Samples were centrifuged at 1,000 $\times g$ for $5 \mathrm{~min}$ and the upper solvent fraction transferred to a clean tube. The aqueous layer was re-extracted by adding $5 \mathrm{~mL}$ of hexane:isopropanol followed by vortexing, phase separation, and centrifugation. The second solvent extraction was combined with the first extraction. The solvent fraction was evaporated under a stream of $\mathrm{N}_{2}$ gas at $40^{\circ} \mathrm{C}$ using an analytical evaporator (N-EVAP model \#112; Organomation Associates Inc., South Berlin, MA). Tubes were reweighed and lipid mass was calculated as final tube weight minus initial tube weight. All samples were run in duplicate.

\section{Histomorphometry and BrdU-Ki67 Dual Labeling}

Paraffin-embedded PAR was used for histological measurements. Methods were essentially as reported previously (Berry et al., 2003b). Briefly, samples were fixed in $10 \%$ formalin overnight and then transferred to $70 \%$ ethanol until processing. At embedding, tissues were dehydrated in graded concentrations of ethanol (70, 80, 95, and 100\%) and cleared using xylene in preparation for infiltration and embedding in paraffin. Embedded tissues were sliced into 5 - $\mu \mathrm{m}$-thick sections using a rotary microtome (model HM340E, Microm International GmbH, Waldorf, Germany). Sections were mounted onto glass slides for subsequent evaluation.

Tissue sections were cleared of paraffin by dipping slides in xylene and then rehydrating in graded alcohol washes and distilled water. Sections were stained with hematoxylin-eosin and photographed at $4 \times$ magnification (6 photomicrographs per sample) using an Olympus BH2 light microscope connected to a QColor3 digital camera (Olympus America Inc., Center Valley, PA). The proportion of epithelial structures present in PAR sections was expressed as a percentage of the total area of the field. Epithelial structures were further classified based on lumen size as large, medium, or small duct, or bud (no lumen present). The total number of epithelial structures per field was counted and averaged for 6 independent photomicrographs.

\section{BrdU-Ki67 Dual Labeling}

Dual labeling was carried as out as described by Capuco (2007). Briefly, paraffin-embedded sectioned PAR samples were deparaffinized in xylene and rehydrated. Slides were boiled in $10 \mathrm{~m} M$ citrate buffer ( $\mathrm{pH}$ 6.0) for antigen retrieval. Individual sections were circled with a PAP barrier pen (cat. no. NC9720458, Fisher Scientific, Pittsburgh, PA). Slides were blocked with CAS Block (cat no. 00-8120; Invitrogen, Chicago, IL) followed by overnight incubation at $4^{\circ} \mathrm{C}$ with a primary antibody cocktail (Ki67 rabbit monoclonal antibody; 1:200; Fisher Scientific) and BrdU mouse monoclonal antibody (1:66.7; Fisher Scientific) diluted in CAS Block. Batch controls received CAS Block instead of primary antibody. Tissue sections were briefly washed in PBS and incubated in combined Alexa 488 goat antimouse IgG (Invitrogen) and Alexa 594 goat anti-rabbit IgG (Invitrogen), both at a final dilution of 1:200. Slides were rinsed in distilled water, and Prolong Gold antifade reagent with 4',6-diamidino-2-phenylindole 
(DAPI, Invitrogen) was added to each slide. Slides were covered with a coverslip and allowed to cure overnight.

\section{Statistics}

The Mixed procedure of SAS (version 9.2, SAS Institute Inc., Cary, NC) was used for analysis of main effects. The main effect of treatment, harvest group and the interaction between the 2 were analyzed. The following model statement was used:

$$
\mathrm{Y}_{\mathrm{ijk}}=\mu+\mathrm{T}_{\mathrm{i}}+\mathrm{G}_{\mathrm{j}}+(\mathrm{TG})_{\mathrm{ij}}+\mathrm{e}_{(\mathrm{ijk})},
$$

where $Y_{\mathrm{ijk}}$ is the dependent variable: mammary gland composition, blood hormone concentration, and gene expression ( $\Delta \mathrm{Ct}$; 3 genes); $\mu$ is the overall mean; $T_{\mathrm{i}}$ is the fixed effect of treatment (bST vs. Sal; $i=1,2$ ); $G_{j}$ is the fixed effect of harvest group ( $65 \mathrm{~d}$ vs. $107 \mathrm{~d} ; \mathrm{j}$ $=1,2) ;(\mathrm{TG})_{\mathrm{ij}}$ is the effect of the interaction between treatment and harvest group; and $\mathrm{e}_{(\mathrm{ijk})}$ is the residual error (assumed to be normally and independently distributed). Results are presented as least squares means \pm standard error of the means. Histometric data related to cell labeling were transformed for statistical analysis as the arcsin of square root to adjust for percentage data. Significance was declared at $P \leq 0.05$, and trends were declared at $P \leq 0.1$.

\section{RESULTS}

\section{Animal Performance and Basic Udder Composition}

Initial BW did not differ between bST- and Saltreated calves. Although no overall effect of bST on weekly weights was observed in either harvest group (Figure 1A), calves in both treatment groups increased BW $(P<0.05)$, and the total gain in 65 -d calves given bST was greater than in 65-d calves given Sal $(P=$ 0.02). Total BW gain for 107-d animals given bST was also numerically higher but the difference was nonsignificant $(P=0.17$; Figure 1B).

As anticipated, total udder mass $(169 \pm 18$ vs. $260 \pm$ $15 \mathrm{~g})$ and dissected PAR $(10 \pm 6$ vs. $58 \pm 6 \mathrm{~g})$ significantly $(P \leq 0.001)$ increased over time $(65-$ vs. $107-d$ harvest). Mass of MFP also tended to increase (62 \pm 10 vs. $90 \pm 9$ g; $P=0.07)$. However, neither total udder weight nor dissected portions of PAR or MFP were significantly affected by treatment with bST.

Table 1 provides mammary development expressed as a proportion of BW. A tendency was observed for bST-treated calves to have reduced mass of total mammary gland per $100 \mathrm{~kg}$ of $\mathrm{BW}(P=0.10)$ but no overall difference was found between total mammary weight in 65 - $\mathrm{d}$ or $107-\mathrm{d}$ calves on a BW basis $(P=0.30)$. Paren- chyma mass expressed per $100 \mathrm{~kg}$ of $\mathrm{BW}$ also did not differ between bST- and Sal-treated calves $(P=0.50)$ but 107-d animals had more PAR per $100 \mathrm{~kg}$ of BW than did 65 -d calves $(P<0.01$; Table 1$)$. Saline-treated calves had significantly more MFP per $100 \mathrm{~kg}$ of BW than did bST-treated animals $(P=0.04)$. Total weight of skin/teat did not differ due to bST $(P=0.66)$ or age at harvest $(P=0.43$; data not shown $)$. Total lymph node mass did not differ due to bST $(P=0.97)$ or age at harvest $(P=0.61$; data not shown).

\section{GH and IGF-I Concentrations}

Blood samples collected $24 \mathrm{~h}$ before and $24 \mathrm{~h}$ after treatment were analyzed for GH and IGF-I concentra-
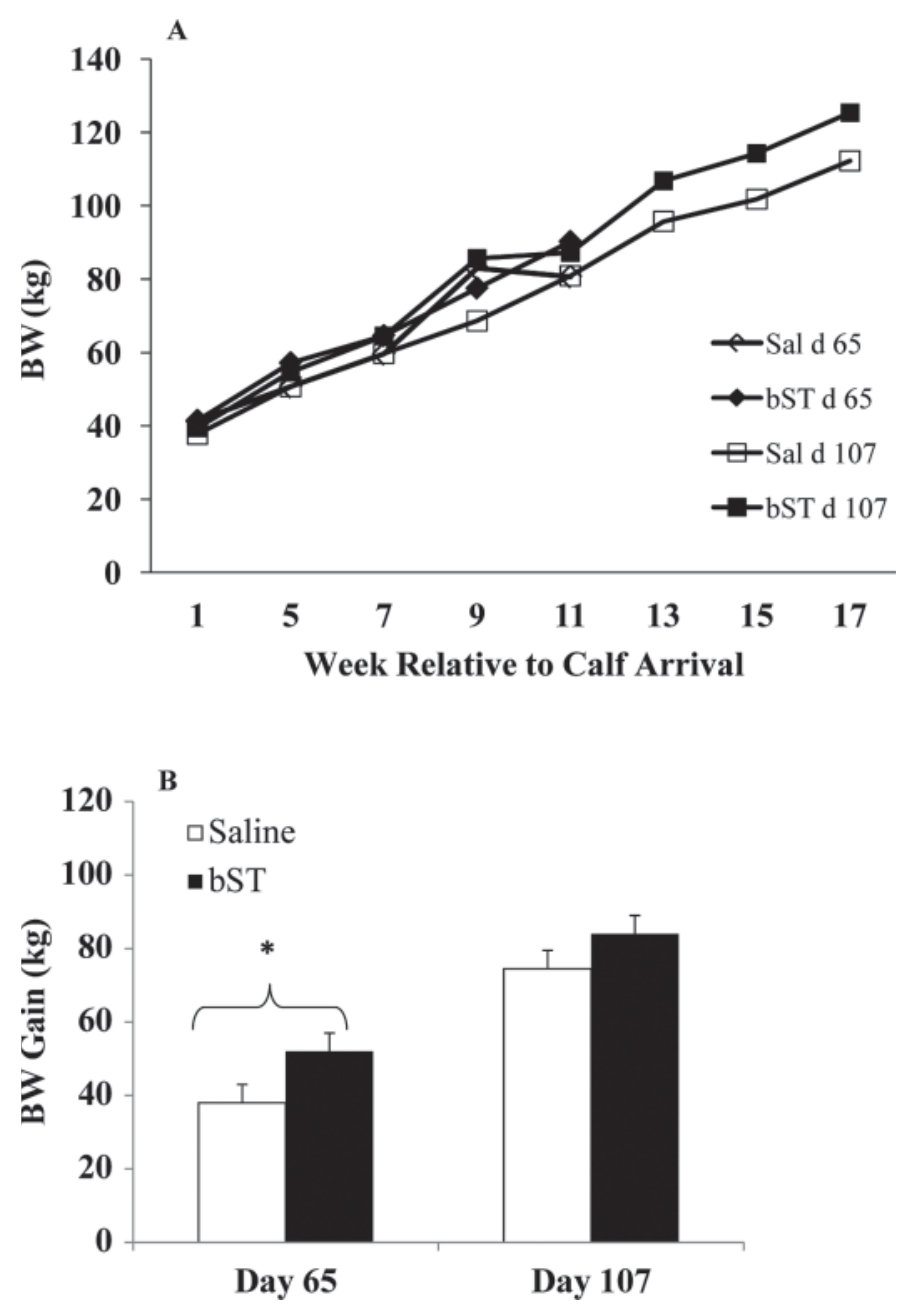

Figure 1. Body weight $(\mathrm{kg})$ and $\mathrm{BW}$ gain $(\mathrm{kg})$ of calves treated with bST $(500 \mathrm{mg}$ ) or placebo (Sal; $0.9 \%$ saline). (A) Treatments were Sal d $65(\mathrm{n}=4)$, bST d $65(\mathrm{n}=4)$, Sal d $107(\mathrm{n}=5)$, and bST d 107 $(\mathrm{n}=5)$. The bST- or Sal-treated animals did not differ in animals harvested at $65 \mathrm{~d}(P=0.44)$ or $107 \mathrm{~d}(P=0.12)$. Heifers in all treatment groups increased overall BW. (B) Calves in the 65 -d group receiving bST gained more BW than Sal-treated heifers $\left({ }^{*} P=0.02\right)$; BW gain did not differ for 107 -d heifers $(P=0.17)$. Data presented are least squares means \pm standard error. 
Table 1. Total udder component weight per $100 \mathrm{~kg}$ of BW in calves treated with bST (500 mg) or placebo (saline; $0.9 \%$ saline) in animals harvested at $65 \mathrm{~d}$ (after 2 treatment injections) or at $107 \mathrm{~d}$ (after 4 injections) ${ }^{1}$

\begin{tabular}{|c|c|c|c|c|c|c|c|}
\hline \multirow[b]{2}{*}{ Component } & \multicolumn{2}{|c|}{ Saline } & \multicolumn{2}{|c|}{ bST } & \multicolumn{3}{|c|}{$P$-value ${ }^{2}$} \\
\hline & Day 65 & Day 107 & Day 65 & Day 107 & Trt & Time & Trt $\times$ time \\
\hline Total parenchyma $(\mathrm{g})$ & $12 \pm 9^{\mathrm{a}}$ & $55 \pm 7^{\mathrm{b}}$ & $12 \pm 7^{\mathrm{a}}$ & $44 \pm 7^{\mathrm{b}}$ & 0.50 & $<0.001$ & 0.44 \\
\hline Total mammary fat pad (g) & $104 \pm 15^{\mathrm{a}}$ & $78 \pm 12^{\mathrm{a}}$ & $47 \pm 13^{\mathrm{b}}$ & $74 \pm 12^{\mathrm{b}}$ & 0.04 & 1.00 & 0.07 \\
\hline
\end{tabular}

${ }^{\mathrm{a}, \mathrm{b}}$ Means within a row with different superscripts differ $(P<0.05)$.

${ }^{1}$ Data are presented as least squares means \pm SEM.

${ }^{2}$ Significance was set at $P \leq 0.05$. Trt $=$ main effect of treatment; time $=$ main effect of harvest time; Trt $\times$ time $=$ treatment $\times$ harvest time interaction.

${ }^{3}$ Total untrimmed udder weight.

tions. Figure 2 summarizes mean responses to bST treatments. Serum concentrations of IGF-I and GH were significantly $(P<0.001)$ increased $24 \mathrm{~h}$ following treatment in both $65-\mathrm{d}$ and $107-\mathrm{d}$ groups. Neither IGF-I nor GH differed $(P>0.1)$ between Sal- and bSTtreated calves in samples taken $24 \mathrm{~h}$ before injection in either $65-\mathrm{d}$ or $107-\mathrm{d}$ calves. However, the average increase in concentration of GH was greater $(P<0.001)$ in 107-d compared with 65 -d calves $(21 \pm 2$ vs. $13 \pm 2$ $\mathrm{ng} / \mathrm{mL})$. Similarly, the increase in IGF-I was greater $(P$ $<0.01)$ in 107-d compared with 65 -d calves $(179 \pm 15$ vs. $85 \pm 18 \mathrm{ng} / \mathrm{mL})$.

\section{Transcript Abundance}

Transcript abundance was measured within PAR and MFP for PCNA and ABC3 (cell proliferation markers) as well as GHR and IGF-I receptor (IGF-IR; Tables 2 and 3). Data presented in Tables 2 and 3 are of $\Delta \mathrm{Ct}$ \pm SEM, and higher values are indicative of reduced gene expression. In PAR, a tendency was observed for decreased expression of PCNA mRNA in bST-treated calves $(P=0.08)$. Additionally, 107-d calves tended to have reduced overall expression of PCNA relative to 65 -d calves $(P=0.07)$. Expression of ABC3 was decreased $(P=0.05)$ in bST-treated compared with Sal-treated calves, but no overall difference was found in ABC3 expression between 65-d and 107-d groups $(P=0.32)$. Relative expression of GHR was reduced in bST-treated calves $(P=0.05)$. Heifers in the $65-\mathrm{d}$ group had greater GHR mRNA expression compared with 107-d calves $(P=0.04)$. Relative expression of IGF-IR did not differ between 65 -d and 107-d groups $(P=0.46)$ or between Sal- and bST-treated calves $(P$ $=0.21$. In MFP, expression of PCNA, ABC3, and GHR did not differ due to treatment. Animals in the 65-d group tended to have greater MFP expression of PCNA compared with $107-\mathrm{d}$ animals $(P=0.06)$. Additionally, bST-treated animals tended to have increased IGF-IR expression compared with Sal-treated animals $(P=0.07)$.

\section{Mammary Gland Composition}

Protein, DNA, and lipid contents of PAR and MFP were measured and expressed as concentration per unit tissue weight of PAR or MFP, total per PAR or MFP, and amount per $100 \mathrm{~kg}$ of BW. In PAR, protein, DNA, and lipid contents did not differ between bST- and Saltreated animals (Table 4). Calves in the 107-d group had more $(P=0.02)$ total protein $(1,837 \pm 357$ vs. $274 \pm 461)$ and more $(P=0.03)$ protein per $100 \mathrm{~kg}$ of BW $(1,588 \pm 324$ vs. $322 \pm 419)$ than those in the 65 -d group. Calves in the 107-d group treated with Sal had a higher $(P=0.02)$ concentration of DNA ( $4 \pm 0.2$ vs. 3 \pm 0.2 ) compared with bST-treated animals. Animals in the 107-d group had a greater $(P<0.01)$ concentration of DNA $(3 \pm 0.2$ vs. $2 \pm 0.2)$, more $(P<0.01)$ total DNA $(193 \pm 2$ vs. $16 \pm 29)$, and more $(P<0.01)$ DNA per $100 \mathrm{~kg}$ of $\mathrm{BW}(164 \pm 17$ vs. $18 \pm 22)$ than 65 -d animals. We found a lower $(P<0.01)$ concentration of lipid in 65-d calves treated with Sal than in those treated with bST $(81 \pm 116$ vs. $586 \pm 116)$.

In MFP, a decrease in protein per $100 \mathrm{~kg}$ of $\mathrm{BW}$ was found for bST-treated animals compared with Saltreated animals (Table 5); lipid content did not differ for bST- or Sal-treated calves. Calves in the 107-d group had more $(P=0.02)$ total protein $(2.6 \pm 0.2$ vs. $1.5 \pm 0.3)$ compared with 65 -d animals. Animals in the 65-d group treated with Sal had more $(P=0.02)$ total protein $(2.8 \pm 0.4$ vs. $0.8 \pm 0.5)$ than 65 -d calves treated with bST. Calves in the 65-d group treated with Sal had more $(P=0.01)$ protein per $100 \mathrm{~kg}$ of BW $(3.9 \pm 0.4$ vs. $0.9 \pm 0.4)$ than 65 -d calves treated with bST. The amount of DNA was greater $(P=0.03)$ in 65 -d calves treated with Sal than in those treated with bST $(131 \pm 25$ vs. $30 \pm 25)$.

\section{Histomorphometry and BrdU-Ki67 Dual Labeling}

The amount of epithelium present per unit area of PAR did not differ between calves treated with bST or Sal $(P=0.52)$ but tended to be greater in 107 -d calves 
A

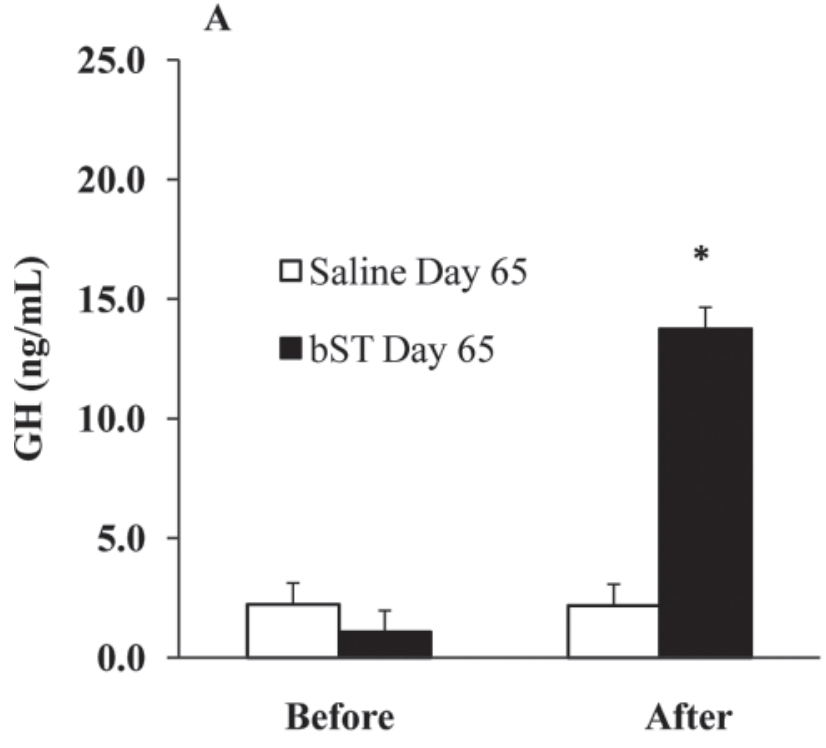

C

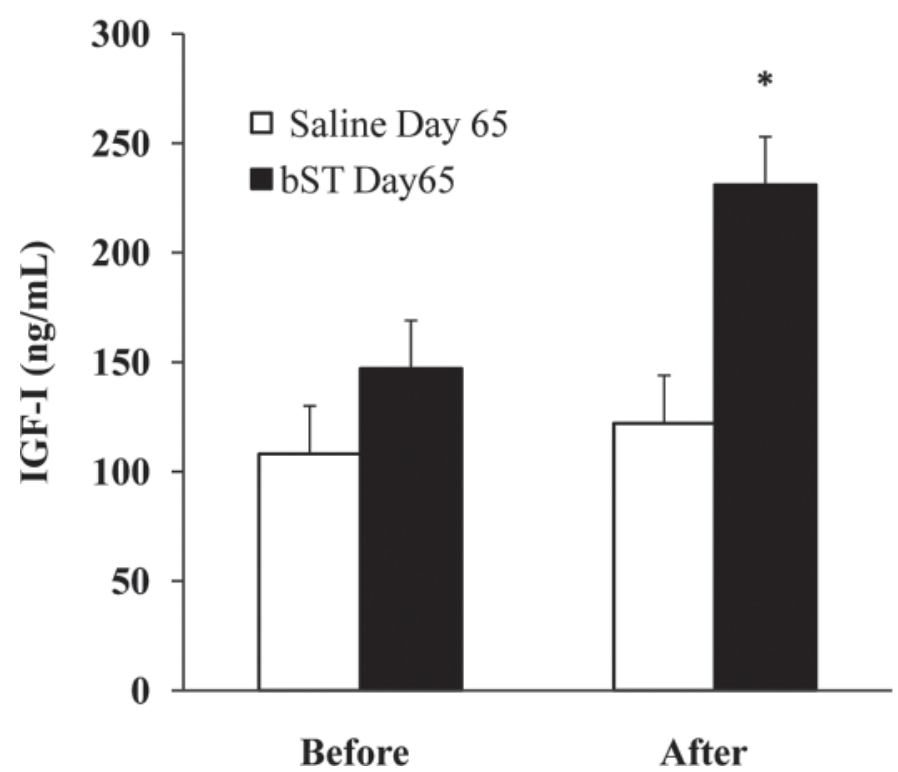

B

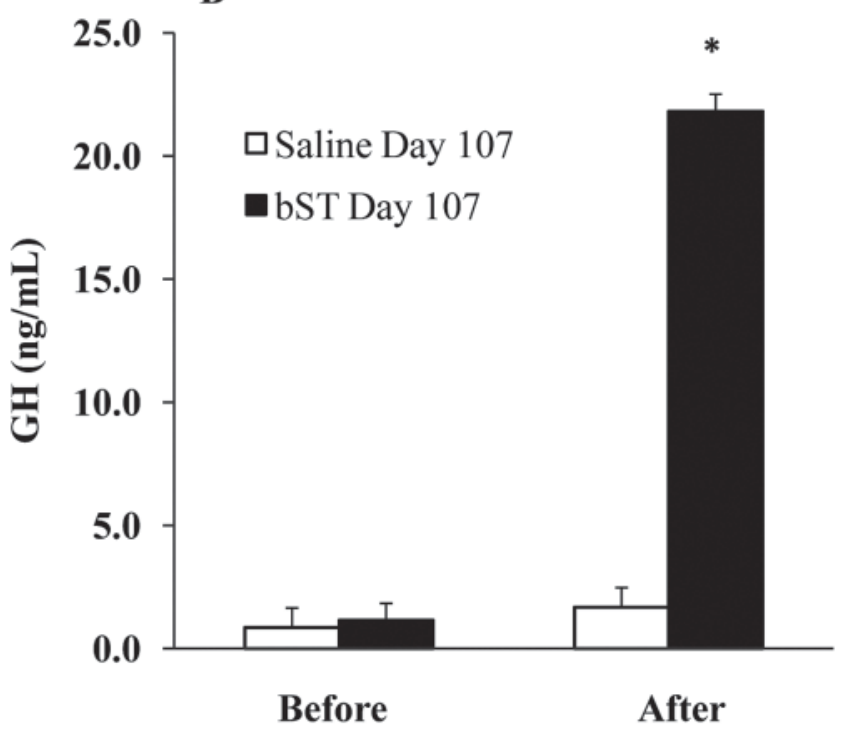

D

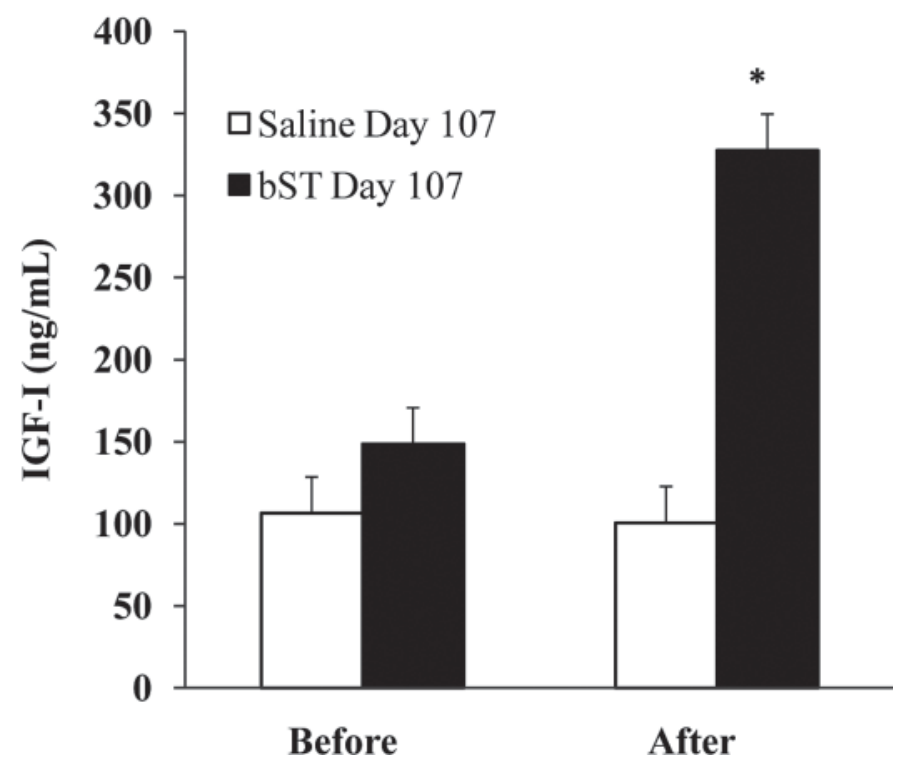

Figure 2. Serum concentrations of growth hormone (GH) and IGF-I before and after treatment with bST for 65-d (panels A and C) and 107-d (panels B and D) heifers. Concentrations of GH and IGF-I were significantly increased $(* P \leq 0.001)$ after treatment, but concentrations of GH or IGF-I did not differ in samples taken before injection in either 65-d or 107-d heifers. In contrast, the average increase in both GH and IGF-I was greater $(P \leq 0.002)$ in 107 -d than in 65 -d calves.

$(P=0.08 ;$ Table 6$)$. In the $65-$ d group, Sal and bST calves averaged $9.9 \pm 2$ and $8.7 \pm 2 \%$ epithelia in PAR, respectively, whereas in 107-d calves, the amount of epithelium present in PAR for Sal and bST was $13.5 \pm$ 2 and $12.2 \pm 2 \%$, respectively.

Classification of different-sized ducts and epithelial structures and their enumeration for bST and Sal animals from 65-d and 107-d groups are given in Table 6. The number of large and medium-sized ducts per field did not differ between bST- and Sal-treated calves or between 65 -d and 107-d groups. However, the number of small ducts, buds, and total number of epithelial structures increased in the 107-d calves compared with 65 -d calves $(P=0.02)$. Overall, we found an average of $3.6 \pm 2$ small ducts per field with 65 -d calves and this was increased to $12.1 \pm 2(P=0.02)$ in the older calves. The number of buds increased from $5.6 \pm 1$ in 65 -d calves to $7.2 \pm 1(P=0.02)$ in 107 -d calves, whereas the total number of epithelial structures was $11.2 \pm 4$ in 65-d calves and $25.9 \pm 4$ in 107-d calves $(P=0.02)$. 
Table 2. Gene expression for proliferating cell nuclear antigen (PCNA), ATPase-binding cassette 3 (ABC3), growth hormone receptor (GHR), and insulin-like growth factor receptor (IGF-IR) of mammary gland parenchyma in calves treated with bST (500 $\mathrm{mg}$ ) or placebo (0.9\% saline) in animals harvested at $65 \mathrm{~d}$ (after 2 treatment injections) or at $107 \mathrm{~d}$ (after 4 injections) ${ }^{1}$

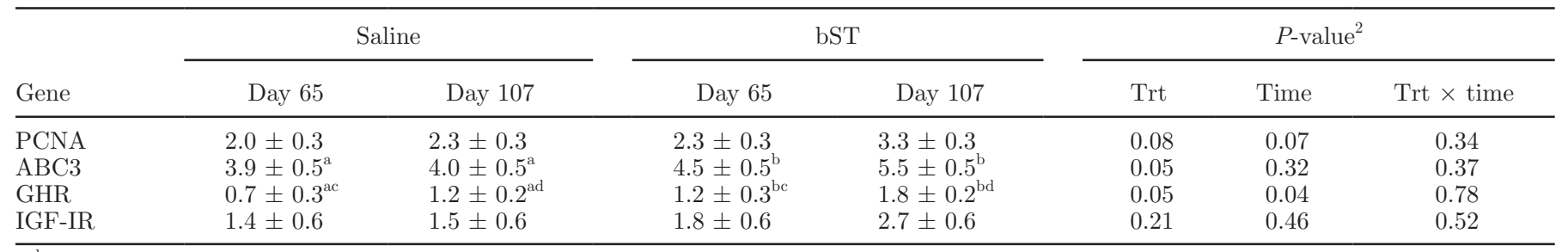

${ }^{\mathrm{a}-\mathrm{d}}$ Means within a row with different superscripts differ $(P<0.05)$.

${ }^{1}$ Data are presented as least squares means [change in cycle threshold $(\Delta \mathrm{Ct}) \pm \mathrm{SEM}$ ]; higher values indicated reduced gene expression.

${ }^{2}$ Significance was set at $P \leq 0.05$. Trt $=$ main effect of treatment; time $=$ main effect of harvest time; Trt $\times$ time $=$ treatment $\times$ harvest time interaction.

Percentage of mammary epithelial cells positive for BrdU and Ki67 in the PAR of bST and Sal animals from 65-d and 107-d calves are shown in Table 7. In the PAR of 65-d calves, an average of 1,207 \pm 65 and $1,181 \pm 89$ cells were counted per calf for Sal and bST, respectively. In 107-d calves, an average of 1,306 \pm 129 and $1,263 \pm 78$ cells were counted for Sal and bST, respectively. Overall, the population of BrdU labelretaining epithelial cells was not affected by bST treatment $(P=0.37)$. An overall decrease in the percentage of BrdU label-retaining cells was observed in 107-d calves compared with 65 -d calves $(0.3 \pm 0.2$ vs. $1.3 \pm$ $0.3 \% ; P=0.005)$. A tendency was observed for $107-\mathrm{d}$ calves treated with bST to have a lower percentage of BrdU-labeled cells compared with 65-d calves treated with Sal $(P=0.06)$. Percentage of Ki67-positive cells (Table 7 ) in the mammary epithelium was not affected by bST treatment $(P=0.42)$, time of harvest $(P=$ $0.27)$, or treatment by time interaction $(P=0.91)$. Of the total cells counted in the mammary epithelium in the 65 - $\mathrm{d}$ animals, $0.3 \pm 0.3 \%$ in Sal and $0.8 \pm 0.3 \%$ in bST were dual-labeled (positive for both BrdU and Ki67; Table 7), whereas in the 107-d animals, $0.4 \pm 0.3$ and $0.5 \pm 0.3 \%$ cells were dual-labeled for BrdU and Ki67 antigens in the Sal and bST animals, respectively. The population of dual-labeled cells in the mammary epithelium did not differ between treatments $(P=0.37)$ or with time of harvest $(P=0.93)$, and no interaction was found between treatment and time $(P=0.58)$. Out of the total number of BrdU label-retaining cells, $35 \%$ were dual-labeled in Sal and 30\% dual-labeled in bST in the 65 -d calves, whereas 39 and $67 \%$ of BrdU labelretaining epithelial cells were dual-labeled in Sal and bST, respectively, in the 107-d group of calves (data not shown).

\section{DISCUSSION}

The importance of GH in mammary gland development has long been established. Classic ablation studies in triply operated rodents showed that GH was necessary for pubertal ductal expansion as well as gestational ductal-alveolar maturation (Lyons, 1958; Tucker, 1981). With research focusing mainly on pregnant and lactating animals, researchers were able to clearly show that GH was a potent galactopoietic hormone in lactating cows (Bauman et al., 1985). In recent years, research interest has shifted to study mammary growth between 3 and 9 mo of age. In some of the earliest work with exogenous GH and young dairy heifers, Sejrsen et al. (1986) showed that bST treatment decreased total mammary gland weight by reducing extraparenchymal

Table 3. Gene expression for proliferating cell nuclear antigen (PCNA), ATPase-binding cassette 3 (ABC3), growth hormone receptor (GHR), and insulin-like growth factor receptor (IGF-IR) of mammary gland mammary fat pad in calves treated with bST (500 mg) or placebo (0.9\% saline) in animals harvested at $65 \mathrm{~d}$ (after 2 treatment injections) or at $107 \mathrm{~d}$ (after 4 injections) ${ }^{1}$

\begin{tabular}{|c|c|c|c|c|c|c|c|}
\hline Gene & \multicolumn{2}{|c|}{ Saline } & \multicolumn{2}{|c|}{ bST } & \multicolumn{3}{|c|}{$P$-value ${ }^{2}$} \\
\hline PCNA & $2.9 \pm 0.3$ & $4.0 \pm 0.3$ & $2.9 \pm 0.3$ & $3.1 \pm 0.3$ & 0.20 & 0.06 & 0.22 \\
\hline GHR & $-0.3 \pm 0.4$ & $-0.1 \pm 0.4$ & $-0.4 \pm 0.4$ & $-0.4 \pm 0.4$ & 0.55 & 0.86 & 0.84 \\
\hline IGF-IR & $1.5 \pm 0.3$ & $2.4 \pm 0.4$ & $1.2 \pm 0.4$ & $1.3 \pm 0.3$ & 0.07 & 0.21 & 0.26 \\
\hline
\end{tabular}

${ }^{1}$ Data are presented as least squares means [change in cycle threshold $(\Delta \mathrm{Ct}) \pm \mathrm{SEM}$ ]; higher values indicated reduced gene expression.

${ }^{2}$ Significance was set at $P \leq 0.05$. Trt $=$ main effect of treatment; time $=$ main effect of harvest time; Trt $\times$ time $=$ treatment $\times$ harvest time interaction. 
Table 4. Proximate composition of mammary gland parenchyma (PAR) in calves treated with bST (500 $\mathrm{mg})$ or placebo (0.9\% saline) in animals harvested at $65 \mathrm{~d}$ (after 2 treatment injections) or at $107 \mathrm{~d}$ (after 4 injections) ${ }^{1}$

\begin{tabular}{|c|c|c|c|c|c|c|c|}
\hline \multirow[b]{2}{*}{ Composition $^{2}$} & \multicolumn{2}{|c|}{ Saline } & \multicolumn{2}{|c|}{ bST } & \multicolumn{3}{|c|}{$P$-value ${ }^{3}$} \\
\hline & Day 65 & Day 107 & Day 65 & Day 107 & Trt & Time & Trt $\times$ time \\
\hline \multicolumn{8}{|l|}{ Protein } \\
\hline$\mu \mathrm{g} / \mathrm{mg}$ of tissue & $42 \pm 10$ & $27 \pm 8$ & $27 \pm 10$ & $36 \pm 8$ & 0.72 & 0.74 & 0.20 \\
\hline total $(\mathrm{mg})$ & $406 \pm 652^{\mathrm{a}}$ & $1,657 \pm 505^{\mathrm{b}}$ & $142 \pm 652^{\mathrm{a}}$ & $2,016 \pm 505^{\mathrm{b}}$ & 0.94 & 0.020 & 0.60 \\
\hline $\mathrm{mg} / 100 \mathrm{~kg}$ of BW & $493 \pm 592^{\mathrm{a}}$ & $1,496 \pm 459^{\mathrm{b}}$ & $150 \pm 592^{\mathrm{a}}$ & $1,680 \pm 456^{\mathrm{b}}$ & 0.88 & 0.03 & 0.63 \\
\hline \multicolumn{8}{|l|}{ DNA } \\
\hline $\mathrm{mg} / 100 \mathrm{~kg}$ of BW & $24 \pm 32^{\mathrm{a}}$ & $201 \pm 24^{\mathrm{b}}$ & $12 \pm 32^{\mathrm{a}}$ & $126 \pm 24^{\mathrm{b}}$ & 0.15 & $<0.01$ & 0.28 \\
\hline \multicolumn{8}{|l|}{ Lipid } \\
\hline $\mathrm{mg} / \mathrm{g}$ of tissue & $81 \pm 116^{\mathrm{a}}$ & $238 \pm 74$ & $586 \pm 116^{\mathrm{b}}$ & $85 \pm 74$ & 0.10 & 0.11 & $<0.01$ \\
\hline total $(\mathrm{g})$ & $0.98 \pm 12$ & $18.7 \pm 8$ & $1.89 \pm 12$ & $4.5 \pm 8$ & 0.54 & 0.35 & 0.48 \\
\hline $\mathrm{g} / 100 \mathrm{~kg}$ of $\mathrm{BW}$ & $0.57 \pm 5$ & $7.8 \pm 3$ & $1.10 \pm 5$ & $1.78 \pm 3$ & 0.51 & 0.35 & 0.44 \\
\hline
\end{tabular}

${ }^{\mathrm{a}-\mathrm{d}}$ Means within a row with different superscripts differ $(P<0.05)$.

${ }^{1}$ Data are presented as least squares means \pm SEM.

${ }^{2}$ Composition (protein, DNA, and lipid) is expressed per mass of dissected PAR for the entire udder.

${ }^{3}$ Significance was set at $P \leq 0.05$. Trt $=$ main effect of treatment; time $=$ main effect of harvest time; Trt $\times$ time $=$ treatment $\times$ harvest time interaction.

tissue but increased PAR tissue mass. Subsequent studies showed that GH specifically stimulated epithelial proliferation (Berry et al., 2001, 2003b). In our current study, we report similar effects on fat deposition in bST-treated glands. However, we did not see the same increase in PAR mass that has been reported previously (Sejrsen et al., 1986; Carstens et al., 1997; Radcliff et al., 1997). Furthermore, biochemical analysis revealed no compositional changes in PAR due to bST. Consistent with our findings, Capuco et al. (2004) reported no effect of bST on PAR mass or composition.

The exact mechanism of GH regulation in mammary gland development remains unclear. It has been sug- gested that the effects of GH on the mammary gland are indirect. Radiolabeled binding assays showed little, if any, specific binding of GH to bovine mammary tissue (McFadden et al., 1990; Purup et al., 1995). However, both GHR mRNA and protein have been detected in the mammary gland, which supports a direct effect of GH (Sinowatz et al., 2000; Plath-Gabler et al., 2001). In the current study, we also detected the presence of GHR mRNA in mammary PAR. Nevertheless, it is important to realize that this does not allow us to determine whether the receptor is expressed within the epithelial cells, or the closely associated stromal cells, or both. However, exogenous bST had no effect on GHR

Table 5. Proximate composition of mammary gland mammary fat pad (MFP) treated with bST (500 mg) or placebo (0.9\% saline) in animals harvested at $65 \mathrm{~d}$ (after 2 treatment injections) or at $107 \mathrm{~d}$ (after 4 injections) ${ }^{1}$

\begin{tabular}{|c|c|c|c|c|c|c|c|}
\hline Composition $^{2}$ & \multicolumn{2}{|c|}{ Saline } & \multicolumn{2}{|c|}{ bST } & \multicolumn{3}{|c|}{$P$-value ${ }^{3}$} \\
\hline$\mu \mathrm{g} / \mathrm{mg}$ of tissue & $28 \pm 3$ & $27 \pm 3$ & $23 \pm 3$ & $33 \pm 3$ & 0.88 & 0.18 & 0.07 \\
\hline total $(\mathrm{g})$ & $2.3 \pm 0.5^{\mathrm{ac}}$ & $2.3 \pm 0.35^{\mathrm{b}}$ & $0.8 \pm 0.45^{\mathrm{ad}}$ & $3.0 \pm 0.4^{\mathrm{b}}$ & 0.26 & 0.02 & 0.02 \\
\hline $\mathrm{g} / 100 \mathrm{~kg}$ of $\mathrm{BW}$ & $3.0 \pm 0.4^{\mathrm{ac}}$ & $2.1 \pm 0.34^{\mathrm{a}}$ & $0.9 \pm 0.44^{\mathrm{bc}}$ & $2.4 \pm 0.3^{\mathrm{b}}$ & 0.04 & 0.40 & 0.01 \\
\hline \multicolumn{8}{|l|}{ DNA } \\
\hline $\mathrm{mg} / 100 \mathrm{~kg}$ of BW & $131 \pm 25$ & $73 \pm 19$ & $30 \pm 25$ & $82 \pm 19$ & 0.060 & 0.910 & 0.03 \\
\hline \multicolumn{8}{|l|}{ Lipid } \\
\hline $\mathrm{mg} / \mathrm{g}$ of tissue & $329 \pm 86$ & $358 \pm 75$ & $475 \pm 106$ & $347 \pm 67$ & 0.45 & 0.57 & 0.38 \\
\hline total $(\mathrm{g})$ & $31 \pm 9$ & $29 \pm 8$ & $22 \pm 11$ & $31 \pm 7$ & 0.68 & 0.67 & 0.52 \\
\hline $\mathrm{g} / 100 \mathrm{~kg}$ of $\mathrm{BW}$ & $40 \pm 10$ & $27 \pm 9$ & $24 \pm 12$ & $25 \pm 8$ & 0.38 & 0.55 & 0.53 \\
\hline
\end{tabular}

${ }^{\mathrm{a}-\mathrm{d}}$ Means within a row with different superscripts differ $(P<0.05)$.

${ }^{1}$ Data are presented as least squares means \pm SEM.

${ }^{2}$ Composition (protein, DNA, and lipid) is expressed per mass of dissected MFP for the entire udder.

${ }^{3}$ Significance was set at $P \leq 0.05$. Trt $=$ main effect of treatment; time $=$ main effect of harvest time; Trt $\times$ time $=$ treatment $\times$ harvest time interaction. 
Table 6. Percentage epithelial cell area and number of epithelial structures in the mammary parenchyma (PAR) in calves treated with bST (500 $\mathrm{mg}$ ) or placebo ( $0.9 \%$ saline) in animals harvested at $65 \mathrm{~d}$ (after 2 treatment injections) or at $107 \mathrm{~d}$ (after 4 injections) ${ }^{1}$

\begin{tabular}{|c|c|c|c|c|c|c|c|}
\hline \multirow[b]{2}{*}{ Structure } & \multicolumn{2}{|c|}{ Saline } & \multicolumn{2}{|c|}{$\mathrm{bST}$} & \multicolumn{3}{|c|}{$P$-value ${ }^{2}$} \\
\hline & Day 65 & Day 107 & Day 65 & Day 107 & Trt & Time & Trt $\times$ time \\
\hline Medium ducts (n) & $4.0 \pm 1.4$ & $6.6 \pm 1.3$ & $2.9 \pm 1.4$ & $4.9 \pm 1.2$ & 0.32 & 0.10 & 0.88 \\
\hline Small ducts $(\mathrm{n})$ & $4.1 \pm 3.4^{\mathrm{a}}$ & $15.8 \pm 3.0^{\mathrm{b}}$ & $3.1 \pm 3.4^{\mathrm{a}}$ & $8.4 \pm 3.0^{\mathrm{b}}$ & 0.21 & 0.02 & 0.33 \\
\hline Buds (n) & $4.0 \pm 1.5^{\mathrm{a}}$ & $7.8 \pm 1.3^{\mathrm{b}}$ & $7.3 \pm 1.2^{\mathrm{a}}$ & $6.6 \pm 1.3^{\mathrm{b}}$ & 0.49 & 0.02 & 0.87 \\
\hline
\end{tabular}

${ }_{\mathrm{a}, \mathrm{b}}$ Means within a row with different superscripts differ $(P<0.05)$.

${ }^{1}$ Data are presented as least squares means \pm SEM.

${ }^{2}$ Significance was set at $P \leq 0.05$. Trt $=$ main effect of treatment; time $=$ main effect of harvest time; Trt $\times$ time $=$ treatment $\times$ harvest time interaction.

mRNA expression in mammary MFP but did decrease expression in samples of PAR. This finding is in partial agreement with Plath-Gabler et al. (2001), who reported consistent GHR mRNA expression across developmental stages. Much evidence suggests that many GHassociated actions are mediated via the potent mammary mitogen IGF-I (Akers et al., 2000; Divisova et al., 2006). Previous reports have also shown a nutritionally dependent concomitant increase in circulating IGF-I levels with administration of exogenous GH (Purup et al., 1993; Vestergaard et al., 1995; Berry et al., 2001). Consistent with these reports, we found that exogenous bST increased circulating concentrations of IGF-I in these calves. Interestingly, both GH and IGF-I concentrations returned to that of the Sal-treated animals by the time of the next treatment injections (Figure 2). Although this is consistent with reports that increases of GH are transient, this decrease in concentration may also indicate a mistiming of our sampling scheme. We presupposed a more prolonged release of $\mathrm{GH}$ over the 21-d period; that is, $23.8 \mathrm{mg} / \mathrm{d}$, if release were assumed to be linear. Further, the overall dosage of bST administered was markedly higher $(\sim 10$-fold) for these calves than what is recommended for use in mature lactating cows on a BW basis; that is, approximately
$500 \mathrm{mg} / 50 \mathrm{~kg}$ in these calves at the time of the first injection compared with approximately $500 \mathrm{mg} / 525 \mathrm{~kg}$ in mature lactating Holstein dairy cows. This was also a part of our reasoning for extending the treatment window from $14 \mathrm{~d}$ (recommended for mature lactating cows) to $21 \mathrm{~d}$ in these calves. We also reasoned that any practical use of bST in heifers would most likely depend on application of the currently commercially available formulation. Clearly, by $21 \mathrm{~d}$, concentrations of GH in Sal- and bST-treated animals were essentially identical, so our assumption of more prolonged release was incorrect. Nonetheless, it is evident that circulating concentrations of $\mathrm{GH}$ were elevated during a portion of the time between injection times.

In older heifers, exogenous GH has been shown to increase $\left[{ }^{3} \mathrm{H}\right]$-thymidine incorporation by mammary epithelia by up to 6-fold (Berry et al., 2001, 2003b). Unexpectedly, we measured a decrease in proliferation in response to bST as assessed by PCNA and ABC3 gene expression. Furthermore, Ki67 immunohistochemistry was similar for bST- and Sal-treated animals. These findings are, however, consistent with Capuco et al. (2004), who reported no effect on Ki67 labeling index. Consistent with previous studies, mammary gland histology was not affected by GH (Sejrsen et al.,

Table 7. Labeling index (\%) for proliferation and putative stem cell markers in the mammary epithelial cells ${ }^{1}$ of calves treated with bST (500 $\mathrm{mg})$ or placebo $(0.9 \% \text { saline) in animals harvested at } 65 \mathrm{~d} \text { (after } 2 \text { treatment injections) or at } 107 \mathrm{~d} \text { (after } 4 \text { injections })^{2}$

\begin{tabular}{|c|c|c|c|c|c|c|c|}
\hline \multirow[b]{2}{*}{ Label } & \multicolumn{2}{|c|}{ Saline } & \multicolumn{2}{|c|}{$\mathrm{bST}$} & \multicolumn{3}{|c|}{$P$-value ${ }^{3}$} \\
\hline & Day 65 & Day 107 & Day 65 & Day 107 & Trt & Time & Trt $\times$ time \\
\hline $\operatorname{BrdU}$ & $0.8 \pm 0.4^{\mathrm{a}}$ & $0.5 \pm 0.3^{\mathrm{b}}$ & $2 \pm 0.4^{\mathrm{a}}$ & $0.1 \pm 0.3^{\mathrm{b}}$ & 0.37 & 0.02 & 0.06 \\
\hline Ki67 & $2 \pm 1$ & $1 \pm 1$ & $3 \pm 1$ & $2 \pm 1$ & 0.42 & 0.27 & 0.91 \\
\hline Dual-labeled & $0.3 \pm 0.3$ & $0.4 \pm 0.3$ & $0.8 \pm 0.3$ & $0.6 \pm 0.3$ & 0.37 & 0.93 & 0.58 \\
\hline
\end{tabular}

${ }^{\mathrm{a}, \mathrm{b}}$ Means within a row with different superscripts differ $(P<0.05)$.

${ }^{1}$ In parenchyma of d-65 harvest, an average of 1,207 \pm 65 (saline) and 1,181 \pm 89 (bST) cells were counted per animal; for 107-d harvest, an average of $1,306 \pm 129$ (saline) and 1,263 \pm 78 (bST) cells were counted per animal.

${ }^{2}$ Data $(\%)$ are presented as least squares means \pm SEM.

${ }^{3}$ Significance was set at $P \leq 0.05$. Trt $=$ main effect of treatment; time $=$ main effect of harvest time; Trt $\times$ time $=$ treatment $\times$ harvest time interaction. 
1986; Purup et al., 1993). Both Sal- and bST-treated glands contained similar histological architecture of large, medium-sized, and small ducts, as well as subtending ducts and terminal ductal units (Capuco and Ellis, 2005).

Increasing attention has been focused on identifying putative stem cells within the bovine mammary gland. Supporting the idea of stem cells is the regenerative ability of the mammary gland. A fully functioning mammary gland can be generated by transplanting regions of murine ductal tree into cleared fat pad (Smith, 2005). The ability to not only detect stem cells but also manipulate them within the bovine mammary gland has possible practical implications for the dairy industry. Ellis and Capuco (2002) reported the presence of lightly staining, BrdU-positive cells in the prepubertal bovine gland and suggested that these may be putative stem cells. They went on to show that this population of cells decreased as the heifers got older. Our current study supports these findings. Although we did not evaluate the staining intensity of mammary epithelial cells, we did evaluate proliferation using BrdU and Ki67. The use of both markers allowed us to not only quantify actively dividing cells (i.e., dual labeled with Ki67/ BrdU) but also detect cells that had previously divided (BrdU). We found that in the PAR of 65-d animals, less than $2 \%$ of the epithelial cells were BrdU-positive, regardless of treatment. This percentage decreased to less than $0.5 \%$ in 107 -d animals. We also noted that less than $3 \%$ of epithelial cells from 65 -d tissues were Ki67positive. Similarly, in 107-d tissues, less than $2 \%$ of epithelial cells stained positive for Ki67. Furthermore, of the BrdU-positive cells, only 30 to $35 \%$ of these cells were also Ki67-positive. This proportion changed in 107-d animals, with $67 \%$ of BrdU-positive cells also staining positive for Ki67. Additionally, we were able to reconcile these data with real-time expression of PCNA, another marker of proliferation, which was not significantly changed by treatment with bST (Table 2 ). This small proportion of dual-labeled positive cells suggests that BrdU-positive/Ki67-negative cells are not actively dividing and may be a population of putative stem cells. It is clear that the study of mammary stem cells, especially in the bovine, is in its infancy. The recent paper by Motyl et al. (2010) strongly suggests that a population of bovine mammary stem cells may be identified by expression of stem cell antigen 1 (Sca-1) coupled with the lack of expression of estrogen receptor. This builds on the work of Capuco et al. (2009), which suggested that estrogen receptor (ER)-negative but BrdU-label retaining cells are mammary stem cells, but ER-positive BrdU-label retaining cells are progenitor cells. Future work to characterize such combined cell staining characteristics should be useful in determining a set of markers that can ultimately accurately identify and quantify bovine mammary epithelial stem cells. Ellis and Capuco (2002) reported that the proportion of lightly staining cells was lowest in areas undergoing rapid proliferation and in more mature areas. We did not evaluate regional differences for BrdU labeling but it would be interesting to see not only if there was a difference in BrdU incorporation by region, but also whether the BrdU-positive/Ki67-negative cells were lightly staining.

Based on our current findings, exogenous GH appears to have little mitogenic effect in the early prepubertal mammary gland. Although this is in contrast to much of the published literature involving older heifers, we can offer several plausible explanations. First, any mitogenic effects might have peaked before the time of tissue sampling. However, this seems unlikely given that PAR mass was not increased in response to bST. Although we might have missed proliferative peaks, the lack of difference in the amount of epithelium present, as well as the lack of difference in the number of different-sized ducts present due to bST, suggests another underlying factor. It is possible that local concentrations of IGF-I were unaffected although we saw increases in circulating IGF-I due to bST administration. Berry et al. (2001) reported no increase in mammary IGF-I mRNA in response to exogenous GH. The naive neonatal gland might be unable to respond to GH. For example, Purup et al. (1993) showed that mammary glands of ovariectomized heifers were unresponsive to exogenous bST, implying a need for ovarian steroid priming. Berry et al. (2003a) reported decreased sensitivity to IGF-I in mammary glands of older prepubertal, ovariectomized heifers. It is plausible, then, that estrogen levels or ovarian function in these heifers were too low to allow for GH-induced stimulation of mammary epithelial cell proliferation. This suggests that some combination of bST and estrogen might markedly alter mammary gland development in calves.

\section{CONCLUSIONS}

We saw minimal effects of bST on the mammary gland. This is in contrast to much published literature that reports dramatic effects of bST on mammary composition and growth. Many of the studies have focused on older pubertal heifers and this may explain some of these results.

\section{ACKNOWLEDGMENTS}

This study was supported by a grant from Monsanto Company (St. Louis, MO; 2006 07-0247-08) to R. M. Akers and S. E. Ellis. 


\section{REFERENCES}

Akers, R. M. 2002. Lactation and the Mammary Gland. 1st ed. Iowa State Press, Ames.

Akers, R. M., T. B. McFadden, W. E. Beal, A. J. Guidry, and H. M. Farrell. 1986. Radioimmunoassay for measurement of bovine alpha-lactalbumin in serum, milk and tissue culture media. J. Dairy Res. 53:419-429.

Akers, R. M., T. B. McFadden, S. Purup, M. Vestergaard, K. Sejrsen, and A. V. Capuco. 2000. Local IGF-I axis in peripubertal ruminant mammary development. J. Mammary Gland Biol. Neoplasia 5:43-51.

Bauman, D. E., P. J. Eppard, M. J. DeGeeter, and G. M. Lanza. 1985. Responses of high-producing dairy cows to long-term treatment with pituitary somatotropin and recombinant somatotropin. J. Dairy Sci. 68:1352-1362.

Berry, S. D., R. D. Howard, P. M. Jobst, H. Jiang, and R. M. Akers. 2003a. Interactions between the ovary and the local IGF-I axis modulate mammary development in prepubertal heifers. J. Endocrinol. 177:295-304.

Berry, S. D., P. M. Jobst, S. E. Ellis, R. D. Howard, A. V. Capuco, and R. M. Akers. 2003b. Mammary epithelial proliferation and estrogen receptor alpha expression in prepubertal heifers: Effects of ovariectomy and growth hormone. J. Dairy Sci. 86:2098-2105.

Berry, S. D., T. B. McFadden, R. E. Pearson, and R. M. Akers. 2001. A local increase in the mammary IGF-1:IGFBP-3 ratio mediates the mammogenic effects of estrogen and growth hormone. Domest. Anim. Endocrinol. 21:39-53.

Capuco, A. V. 2007. Identification of putative bovine mammary epithelial stem cells by their retention of labeled DNA strands. Exp. Biol. Med. 232:1381-1390.

Capuco, A. V., and R. M. Akers. 2010. Management and environmental influences on mammary gland development and milk production. Chapter 9, Pages 259-292 in Managing the Prenatal Environment to Enhance Livestock Productivity. P. L. Greenwood, A. W. Bell, P. E. Vercoe, and G. J. Viljoen, ed. Springer Science+Business Media, Berlin, Germany.

Capuco, A. V., G. E. Dahl, D. L. Wood, U. Moallem, and R. E. Erdman. 2004. Effect of bovine somatotropin and rumen-undegradable protein on mammary growth of prepubertal dairy heifers and subsequent milk production. J. Dairy Sci. 87:3762-3769.

Capuco, A. V., and S. E. Ellis. 2005. Bovine mammary progenitor cells: Current concepts and future directions. J. Mammary Gland Biol. Neoplasia 10:5-15.

Capuco, A. V., C. M. Evock-Clover, A. Minuti, and D. L. Wood. 2009. In vivo expansion of the mammary stem/progenitor cell population by xanthosine infusion. Exp. Biol. Med. 234:475-482.

Capuco, A. V., J. J. Smith, D. R. Waldo, and C. E. Rexroad Jr. 1995. Influence of prepubertal dietary regimen on mammary growth of Holstein heifers. J. Dairy Sci. 78:2709-2725.

Carstens, G. E., D. E. Glaser, F. M. Byers, L. W. Greene, and D. K. Lunt. 1997. Effects of bovine somatotropin treatment and intermittent growth pattern on mammary gland development in heifers. J. Anim. Sci. 75:2378-2388.

Divisova, J., I. Kuiatse, Z. Lazard, H. Weiss, F. Vreeland, D. L. Hadsell, R. Schiff, C. K. Osborne, and A. V. Lee. 2006. The growth hormone receptor antagonist pegvisomant blocks both mammary gland development and MCF-7 breast cancer xenograft growth. Breast Cancer Res. Treat. 98:315-327.

Ellis, S., and A. V. Capuco. 2002. Cell proliferation in bovine mammary epithelium: Identification of the primary proliferative cell population. Tissue Cell 34:155-163.

Hara, A., and N. S. Radin. 1978. Lipid extraction of tissues with a low-toxicity solvent. Anal. Biochem. 90:420-426.

Lyons, W. R. 1958. Hormonal synergism in mammary growth. Proc. R. Soc. Lond. B Biol. Sci. 149:303-325.
McFadden, T. B., T. E. Daniel, and R. M. Akers. 1990. Effects of plane of nutrition, growth hormone and unsaturated fat on growth hormone, insulin and prolactin receptors in prepubertal lambs. J. Anim. Sci. 68:3180-3189.

Meyer, M. J., A. V. Capuco, D. A. Ross, L. M. Lintault, and M. E. Van Amburgh. 2006. Developmental and nutritional regulation of the prepubertal heifer mammary gland: I. Parenchyma and fat pad mass and composition. J. Dairy Sci. 89:4289-4297.

Motyl, T., J. B. Bierla, M. Kozlowski, M. Gajewska, B. Gajkowska, and M. Kolronkiewicz. 2010. Identification, quantification and transcriptional profile of potential stem cells in the bovine mammary gland. Livest. Sci. 136:136-149.

Piantoni, P., M. Bionaz, D. E. Graugnard, K. M. Daniels, R. M. Akers, and J. J. Loor. 2008. Gene expression ratio stability evaluation in prepubertal bovine mammary tissue from calves fed different milk replacers reveals novel internal controls for quantitative polymerase chain reaction. J. Nutr. 138:1158-1164.

Plath-Gabler, A., C. Gabler, F. Sinowatz, B. Berisha, and D. Schams. 2001. The expression of the IGF family and GH receptor in the bovine mammary gland. J. Endocrinol. 168:39-48.

Purup, S., K. Sejrsen, and R. M. Akers. 1995. Effect of bovine GH and ovariectomy on mammary tissue sensitivity to IGF-I in prepubertal heifers. J. Endocrinol. 144:153-158.

Purup, S., K. Sejrsen, J. Foldager, and R. M. Akers. 1993. Effect of exogenous bovine growth hormone and ovariectomy on prepubertal mammary growth, serum hormones and acute in vitro proliferative response of mammary explants from Holstein heifers. J. Endocrinol. 139:19-26.

Radcliff, R. P., M. J. VandeHaar, A. L. Skidmore, L. T. Chapin, B. R. Radke, J. W. Lloyd, E. P. Stanisiewski, and H. A. Tucker 1997. Effects of diet and bovine somatotropin on heifer growth and mammary development. J. Dairy Sci. 80:1996-2003.

Sejrsen, K., J. Foldager, M. T. Sorensen, R. M. Akers, and D. E. Bauman. 1986. Effect of exogenous bovine somatotropin on pubertal mammary development in heifers. J. Dairy Sci. 69:1528-1535.

Sejrsen, K., J. T. Huber, and H. A. Tucker. 1983. Influence of amount fed on hormone concentrations and their relationship to mammary growth in heifers. J. Dairy Sci. 66:845-855.

Sejrsen, K., S. Purup, M. Vestergaard, and J. Foldager. 2000. High body weight gain and reduced bovine mammary growth: Physiological basis and implications for milk yield potential. Domest. Anim. Endocrinol. 19:93-104.

Sharma, B. K., M. J. Vandehaar, and N. K. Ames. 1994. Expression of insulin-like growth factor-I in cows at different stages of lactation and in late lactation cows treated with somatotropin. J. Dairy Sci. $77: 2232-2241$.

Sinha, Y. N., and H. A. Tucker. 1969. Mammary development and pituitary prolactin level of heifers from birth through puberty and during the estrous cycle. J. Dairy Sci. 52:507-512.

Sinowatz, F., D. Schams, S. Kolle, A. Plath, D. Lincoln, and M. J. Waters. 2000. Cellular localisation of GH receptor in the bovine mammary gland during mammogenesis, lactation and involution. J. Endocrinol. 166:503-510.

Smith, G. H. 2005. Label-retaining epithelial cells in mouse mammary gland divide asymmetrically and retain their template DNA strands. Development 132:681-687.

Tucker, H. A. 1981. Physiological control of mammary growth, lactogenesis, and lactation. J. Dairy Sci. 64:1403-1421.

Vestergaard, M., S. Purup, P. Henckel, E. Tonner, D. J. Flint, L. R. Jensen, and K. Sejrsen. 1995. Effects of growth hormone and ovariectomy on performance, serum hormones, insulin-like growth factor-binding proteins, and muscle fiber properties of prepubertal Friesian heifers. J. Anim. Sci. 73:3574-3584.

Weber, M. S., S. Purup, M. Vestergaard, R. M. Akers, and K. S. Sejrsen. 1999. Contribution of IGF-I to mitogenic activity in mammary extracts and serum. J. Endocrinol. 161:365-373. 